\title{
The urban heat island in the city of Poznań as derived from Landsat 5 TM
}

\author{
Agnieszka Majkowska $^{1}$ - Leszek Kolendowicz ${ }^{1}$ - Marek Pólrolniczak ${ }^{1}$. \\ Jan Hauke $^{2} \cdot$ Bartosz Czernecki $^{1}$
}

Received: 22 January 2014 / Accepted: 19 January 2016 / Published online: 1 February 2016

(C) The Author(s) 2016. This article is published with open access at Springerlink.com

\begin{abstract}
To study urban heat island (UHI), Landsat 5 TM data and in situ measurements of air temperature from nine points in Poznan (Poland) for the period June 2008-May 2013 were used. Based on data from measurement points located in different types of land use, the surface urban heat island (SUHI) maps were created. All available and qualitycontrolled Landsat 5 TM images from 15 unique days were used to obtain the characteristics of land surface temperature (LST) and UHI intensity. In addition, spatial analysis of UHI was conducted on the basis of Corine Land Cover 2006 dataset. In situ measurements at a height of $2 \mathrm{~m}$ above ground level show that the UHI is a common occurrence in Poznan with a mean annual intensity of $1.0^{\circ} \mathrm{C}$. The UHI intensity is greater during the warm half of the year. Moreover, results based on the remote sensing data and the Corine Land Cover 2006 indicate that the highest value of the mean LST anomalies $\left(3.4^{\circ} \mathrm{C}\right)$ is attained by the continuous urban fabric, while the lowest value occurs within the broad-leaved forests $\left(-3.1^{\circ} \mathrm{C}\right)$. To re-count from LST to the air temperature at a height of $2 \mathrm{~m}$ above ground level $\left(T_{\mathrm{ag}}\right)$, linear and non-linear regression models were created. For both models, coefficients of determination equal about 0.80 , with slightly higher value for the non-linear approach, which was applied to estimate the $T_{\text {agl }}$ spatial variability over the city of Poznan.
\end{abstract}

Agnieszka Majkowska agma@amu.edu.pl

1 Department of Climatology, Adam Mickiewicz University, Dzięgielowa 27, 61-680 Poznań, Poland

2 Department of Regional Analysis, Adam Mickiewicz University, Dzięgielowa 27, 61-680 Poznań, Poland

\section{Introduction}

The phenomenon of an urban heat island (UHI), consisting of a significant increase in urban area's temperature with respect to the surrounding suburban and rural neighborhoods, has been known and studied since the nineteenth century (Landsberg 1981; Fortuniak and Kłysik 2008). In the early phase of those UHI studies, researchers concentrated on ground-based meteorological data, with focus on a comparative analysis of those data (Arnfield 2003; Stewart 2011). Oke (1979) determined that UHI (or atmospheric UHI) can also be defined for the urban canopy layer (UCL) and urban boundary layer (UBL). The UCL observations contain in situ measurements or data from sensors mounted on mobile platforms (using cars and bicycles). The UCL consists of air volume which is contained between urban buildings and other rough elements. In the case of UBL (i.e., a layer above UCL), the data comes from instruments mounted on special platforms, balloons, or aircraft (Voogt and Oke 2003). The air in the UCL is affected by the surroundings, mainly artificial surfaces, materials, and their geometry (in the microscale). In considering UBL, the local or mesoscale concept can be discussed. The UBL becomes part of the planetary boundary layer whose characteristics are modified by the actual presence of an urban area as its lower boundary (Oke 1976).

So far, it has been found that the effect of UHI is best marked in the summer and warmer part of the year (Oke 1982; Kłysik and Fortuniak 1999; Philandras et al. 1999; Morris et al. 2001), while in a daily cycle, the highest intensity of UHI occurs at night (Ripley et al. 1996; Jauregui 1997; Magee et al. 1999; Montavez et al. 2000; Tereshchenko and Filonov 2001; Dousset and Gourmelon 2003). The intensity of UHI decreases as cloudiness and wind speed increase (Oke 1982; Voogt 2004) and is greatest during anticyclonic conditions (Oke 1988; Morris and Simmonds 2000; Arnfield 2003). 
There is also a clear relationship between city size and the magnitude of UHI - the latter is linearly correlated with the population logarithm. In large American cities during favorable weather conditions, the intensity of UHI can exceed $12{ }^{\circ} \mathrm{C}$ while in European cities it often reaches $10{ }^{\circ} \mathrm{C}$ (Oke 1973). In Rotterdam, the highest maximum UHI is found in late spring and summer with 95 percentile values from $4.3{ }^{\circ} \mathrm{C}$ to more than $8{ }^{\circ} \mathrm{C}$ (Steeneveld et al. 2011; van Hove et al. 2015).

In Poland as well, the atmospheric UHI is a common occurrence, and this phenomenon has been thoroughly investigated with in situ measurements among most of the biggest Polish agglomerations, providing some fairly specific conditions in each of the analyzed locations. For instance, in Wrocław, the average UHI intensity is ca. $1.0{ }^{\circ} \mathrm{C}$ (Szymanowski 2004). The intensity of UHI in Kraków has decreased since 1990 while remaining higher in the cold half of the year $\left(0.5-1.0^{\circ} \mathrm{C}\right.$, Bokwa 2010). The maximal intensity of UHI in Kraków exceeds $8^{\circ} \mathrm{C}$. Kaszewski and Siwek (1998) found that the maximal intensity of UHI in Lublin is around $3{ }^{\circ} \mathrm{C}$ which occurs in summer during night hours. StopaBoryczka et al. (2001) show that the maximal intensity of UHI in Warsaw occurs in summer and may reach as much as 10 to $12^{\circ} \mathrm{C}$.

A traditional point-wise character of investigating UHI does not allow for recognizing a spatial structure of this phenomenon in every detail. Therefore, nowadays, more and more studies try to characterize the UHI phenomenon using remote sensing data. The first publication based on satellite data was by Rao (1972). Since then, more and more analyses have been based on remote sensing data in urban climate studies. Kawashima et al. (2000) used Landsat 5 TM data to investigate relations between surface temperature and air temperature in the central part of Japan during three winter nights. Voogt and Oke (2003) pointed out that the UHI observed from thermal remote sensing data is none other than the surface urban heat island (SUHI). In the North China Plane, an attempt at air temperature retrieval from Moderate Resolution Imaging Spectroradiometer (MODIS) data was made by Sun et al. (2005). The coefficient of determination of the linear model in predicting the air temperature based on MODIS data is about 0.80. In Madrid, based on SEVIRI and MODIS data, the maximal intensity of SUHI in the summer months can reach $5{ }^{\circ} \mathrm{C}$ (Fabrizi et al. 2011), while in Rome, it is 3 to $4{ }^{\circ} \mathrm{C}$ during nighttime and negative or almost zero SUHI intensity during daytime (Fabrizi et al. 2010).

Specific local issues may arise while using remote sensing techniques to recognize the local features of SUHI. Dobrovolny (2013) studied the SUHI in Brno (Czech Republic) in terms of land cover categories, vegetation cover, and building density. Schwarz et al. (2011) presented several SUHI indicators obtained from various remote sensing data: difference between urban and agricultural areas, urban and water surfaces, hot island area (area with land surface temperature (LST) higher than the mean plus one standard deviation), or micro-SUHI (as a percentage of the area with LST that is higher than the warmest LST associated with tree canopies). Bechtel et al. (2012) indicated that phenological conditions may affect correlation calculations, e.g., between LST and normalized difference vegetation index (NDVI). They suggested that the fraction of active vegetation is a better predictor of LST than NDVI. Schwarz et al. (2012) calculated the mean LST values for selected land classes, and their results showed that the highest mean difference between evening and morning LST occurred in industrial areas (industrial units, roads, railways, and associated lands).

Keeping the aforementioned in mind, the main objective of this paper is to characterize the spatial variability of the SUHI and UHI in Poznań based on Landsat 5 TM images and in situ measurements. The next objective is to build a statistical model for estimating air temperature at a height of $2 \mathrm{~m}$ a.g.l. directly from the Landsat $5 \mathrm{TM}$ data.

\section{Study area and data}

\subsection{City of Poznań}

Poznań $\left(52^{\circ} 18^{\prime}-52^{\circ} 30^{\prime} \mathrm{N}, 16^{\circ} 48^{\prime}-17^{\circ} 04^{\prime} \mathrm{E}\right)$ is the fifth biggest city in Poland with a population of over 554,000 and an area of $261.91 \mathrm{~km}^{2}$ (Fig. 1). The city of Poznań is located in the Wielkopolskie Lakeland (Kondracki 2002) on an elevation from 50 to $154 \mathrm{~m}$ amsl. More than $58 \%$ of its territory is in the plateau areas (higher than $80 \mathrm{~m}$ amsl), about $7 \%$ is in the Warta River valley, and less than $35 \%$ in the upper terraces of the river. The Warta River flows through the city from south to north for a distance of $22.8 \mathrm{~km}$. Within the administrative boundaries of Poznan, there are also natural (glacial origin) and artificial lakes, covering altogether $1.9 \%$ of the city area.

Urbanized areas comprise $43 \%$ of the territory of Poznań including residential (25\%), transport (13\%), and industrial $(5 \%)$ areas. The urban structure is dominated by fragmented and diverse forms of development that are distinguished by a concentration of large areas of modernist housing estates (20\% of the city's invested area) and inner-city neighborhoods and areas with single-family housing ( $45 \%$ of the city's invested areas). The green urban areas were created as a wedge-ring system that consists of two major components: four green wedges that radiate out from the center to the borders of the city and a second one that consists of three concentric rings. In Poznań, forest cover amounts to $13.7 \%$ (Central Statistical 2012).

Poznań is located in the transition zone between continental and oceanic temperate climate zones with mainly oceanic influences. The average annual temperature in Poznan is $8.3{ }^{\circ} \mathrm{C}$, with the highest in July $\left(18.1^{\circ} \mathrm{C}\right)$ and the lowest in 

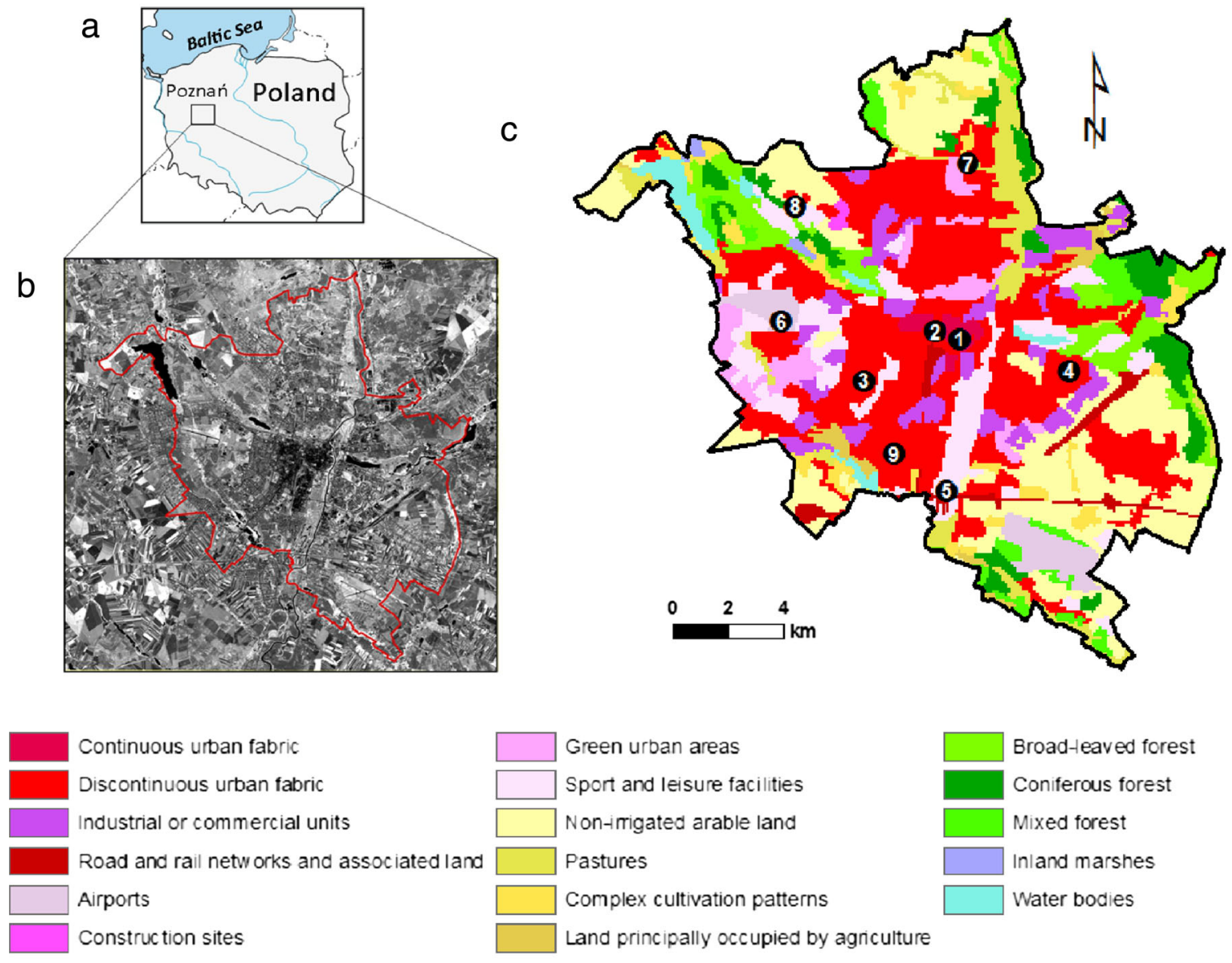

Measurement point 1 - Piekary, 2 - Coll. Minus, 3 - Słoneczna, 4 - Rusa, 5 - Dębina, 6 - Ławica, 7 - Coll. Geographicum, 8 - Strzeszyn, 9 - Swierczewo

Fig. 1 Location of the study area within Poland (a), Landsat 5TM scene (band 4 near-infrared) with administrative border of Poznań (red line) (b), and location of measurement points and types of land cover according to Corine Land Cover 2006 (c)

January $\left(-1.6^{\circ} \mathrm{C}\right)$ (Woś 2010$)$. The average annual precipitation is $517 \mathrm{~mm}$ (as measured in the period 1951-2000), with the highest precipitation in July $(75 \mathrm{~mm})$ and the lowest in February $(26 \mathrm{~mm})$. During the year, the study area is reached for the most part by polar air masses coming from the west at a frequency of about $70 \%$.

\subsection{Remote sensing and in situ dataset}

In order to characterize the spatial variability of SUHI, thermal remote sensing data were used on the basis of cloud-free Landsat 5 TM imageries (path/row 190/24 or 191/23) acquired from the NASA Earth Explorer website (http:// earthexplorer.usgs.gov). Only 15 imageries were usable due to frequent cloud cover over Poznań. The first scene used in this research was acquired on 14 June 2009 and the last one on 3 October 2011. All of the abovementioned data concern the warm half of the year, and the scene center scan time differs from 09:30 UTC to 09:40 UTC. In situ measurement network consists of nine meteorological stations located in different types of land cover and parts of urban space (Fig. 1). The measurements of air temperature were carried out in 30-min intervals during the period from June 2008 to May 2013 by data loggers HOBO U23-001. The accuracy of HOBO loggers is $0.2{ }^{\circ} \mathrm{C}$ which is equal to the accuracy of the Vaisala HMP 45 sensor at the synoptic airport station, Ławica. The loggers are located at a height of $2 \mathrm{~m}$ a.g.l. in anti-radiation shields, with the exception of data obtained from the synoptic station Lawica (airport) run by the IMGW-PIB (Institute of Meteorology and Water Management - National Research Institute).

The basic characteristics of measurement points such as longitude, latitude, distance from the city center, sky view factor (SVF), and type of land cover (according to Corine Land 2006) are shown in Table 1.

Five data points represent the various types of urban development. Two measurement points-Piekary and Collegium Minus - are located in the city center, an area characterized by continuous and historic buildings. In this area, the predominant height of buildings is five stories. Measurement point Piekary is located at a car park on Piekary Street. This location is characterized by four- to 
Table 1 Characteristics of measurement points

\begin{tabular}{|c|c|c|c|c|c|c|}
\hline & Location & Latitude $[\mathrm{N}]$ & Longitude [E] & $\begin{array}{l}\text { Distance from the city } \\
\text { center-Piekary }[\mathrm{km}] / \text { direction }\end{array}$ & SVF (sky view factor) & Land cover \\
\hline 1 & Piekary & $52^{\circ} 24^{\prime} 19.96^{\prime \prime}$ & $16^{\circ} 55^{\prime} 39.60^{\prime \prime}$ & $0.0 /-$ & 0.60 & Continuous urban fabric \\
\hline 2 & Collegium Minus & $52^{\circ} 24^{\prime} 31.13^{\prime \prime}$ & $16^{\circ} 54^{\prime} 53.22^{\prime \prime}$ & $0.9 / \mathrm{W}$ & 0.71 & Continuous urban fabric \\
\hline 3 & Słoneczna & $52^{\circ} 23^{\prime} 40.27^{\prime \prime}$ & $16^{\circ} 52^{\prime} 29.69^{\prime \prime}$ & $3.9 / \mathrm{W}$ & 0.81 & Green urban areas \\
\hline 4 & Rusa & $52^{\circ} 23^{\prime} 29.65^{\prime \prime}$ & $16^{\circ} 59^{\prime} 0.75^{\prime \prime}$ & 4.0/SE & 0.86 & Discontinuous urban fabric \\
\hline 5 & Dębina & $52^{\circ} 21^{\prime} 19.88^{\prime \prime}$ & $16^{\circ} 54^{\prime} 46.14^{\prime \prime}$ & $5.7 / \mathrm{S}$ & 0.79 & Sport and leisure facilities \\
\hline 6 & Ławica & $52^{\circ} 24^{\prime} 59.46^{\prime \prime}$ & $16^{\circ} 50^{\prime} 4.71^{\prime \prime}$ & $6.9 / \mathrm{W}$ & 0.99 & Airports \\
\hline 7 & Collegium Geographicum & $52^{\circ} 27^{\prime} 46.80^{\prime \prime}$ & $16^{\circ} 56^{\prime} 28.92^{\prime \prime}$ & $6.7 / \mathrm{N}$ & 0.82 & Pastures \\
\hline 8 & Strzeszyn & $52^{\circ} 27^{\prime} 15.14^{\prime \prime}$ & $16^{\circ} 50^{\prime} 50.79^{\prime \prime}$ & 7.7/NW & 0.79 & Discontinuous urban fabric \\
\hline 9 & Świerczewo & $52^{\circ} 22^{\prime} 11.90^{\prime \prime}$ & $16^{\circ} 53^{\prime} 56.11^{\prime \prime}$ & $4.5 / \mathrm{S}$ & 0.72 & Discontinuous urban fabric \\
\hline
\end{tabular}

five-story buildings and the Marshal Office of the Wielkopolska Region (11 floors). The Collegium Minus is located next to academic buildings and railway. This area is characterized by a more open urban space than previously described which is clearly visible in the SVF values (Table 1). The SVF is calculated by means of "fish-eye" images in the BMSky-view software.

Another data point was located in a residential area south of the city center (Rusa). The area includes buildings of different heights, while the surrounding area includes housing estates founded in the 80 s. Predominant are buildings with a height of six to nine stories. In the nearest neighborhood to the measurement point, there are apartment blocks of four, ten, and even 16 stories.

Two further points were located in a discontinuous urban fabric. The type of detached houses scattered throughout the north-western part of Poznań represents point Strzeszyn (number 8), while compact detached houses are located in the southern part of Poznan (Świerczewo station). In both positions, prevailing buildings are as high as two stories (up to $7 \mathrm{~m}$ ). The next measurement points are represented by the area near to the surface water (Dębina — sport and leisure facilities), a peripheral area of low buildings located in the northern part of Poznań (Collegium Geographicum — pastures), and green urban areas (Słoneczna). The Słoneczna point is set up within the Astronomical Observatory of Adam Mickiewicz University.

\section{Methods}

The intensity of UHI was defined as the difference in air temperature between particular measurement points and the synoptic station Ławica (airport), which is considered the reference station. Despite the fact that Ławica (airport) lies within the administrative boundaries of Poznań, it may be regarded partly as a rural station due to its peripheral location
(Półrolniczak et al. 2015). According to Koczorowska and Farat (2006), the average annual differences in air temperature between Lawica (airport) and meteorological stations located around Poznań do not exceed $0.1{ }^{\circ} \mathrm{C}$, while $50-80 \%$ of daily means differ only by about $0.0-0.2{ }^{\circ} \mathrm{C}$. A similar approach regarding UHI research was established in other Polish cities, e.g., Warsaw, Wrocław, and Kraków (Stopa-Boryczka et al. 2001; Szymanowski 2004; Bokwa 2010).

In order to obtain the UHI maps based on the meteorological station data, the ordinary kriging method $(\mathrm{OK})$ was used. This method assumes that the distance between sample points is spatially correlated, as often observed in terms of spatial intensity of UHI, and there is no constant data trend over the area of investigation (Childs 2004). Moreover, OK provides usually acceptable spatial variability of the UHI phenomenon in comparison to highly sophisticated regression techniques (Szymanowski and Kryza 2009).

In order to calculate the LST derived from Landsat 5 thermal infrared images, a few additional pre-processing procedures need to be applied. First of all, the raw data (with a spatial resolution of $30 \times 30 \mathrm{~m}$ ) have to be re-calculated to an energy radiation value by means of linear calibration. It requires applying this method to every single spectral band, including the day of image registration in the formula proposed by Walawender (2009):

$\mathrm{Ls}=\left(\frac{\mathrm{Lmax}-\mathrm{Lmin}}{255}\right) \mathrm{DN}+\mathrm{Lmin}$

\section{4 where:}

Ls Energy radiation $\left[\mathrm{W} \mathrm{m}^{-2} \mathrm{sr}^{-1} \mu \mathrm{m}^{-1}\right]$

Lmax Maximum value of energy radiation for each scene $\left[\mathrm{W} \mathrm{m}{ }^{-2} \mathrm{sr}^{-1} \mu \mathrm{m}^{-1}\right.$ ]

Lmin Minimal value of energy radiation for each scene $\left[\mathrm{W} \mathrm{m}{ }^{-2} \mathrm{sr}^{-1} \mu \mathrm{m}^{-1}\right.$ ] 
DN Digital number (value of each pixel, band 6 thermal infrared)

To calculate the radiation temperature, a modified Planck's formula must be used as follows (Chander and Markham 2003):

$T_{\mathrm{R}}=\frac{K_{2}}{\ln \left(\frac{K_{1}}{\mathrm{Ls}}+1\right)}$

where:

$T_{\mathrm{R}} \quad$ Radiation temperature (brightness temperature) $[\mathrm{K}]$

Ls Energy radiation [W $\mathrm{m}^{-2} \mathrm{sr}^{-1} \mu \mathrm{m}^{-1}$ ]

$K_{1} \quad$ Landsat 5 calibration constant $=607.76$

[W m ${ }^{-2} \mathrm{sr}^{-1} \mathrm{\mu m}^{-1}$ ]

$K_{2} \quad$ Landsat 5 calibration constant $=1260.56[\mathrm{~K}]$

Before calculating the emissivity in urban areas, it would be very useful to apply a plant coverage to the area of interest. One of the most common vegetation indices used in this approach (Sobrino and Raissouni 2000; Walawender 2009) is NDVI, which can be calculated using the formula proposed by Lillesand and Kiefer (2004):

$\mathrm{NDVI}=\frac{\mathrm{NIR}-\mathrm{VIS}}{\mathrm{NIR}+\mathrm{VIS}}$

where:

NIR

Near-infrared spectral band (wavelength for Landsat 5 TM 0.76-0.90 $\mu \mathrm{m})$

VIS Visible spectral band (wavelength for Landsat 5 TM 0.63-0.69 $\mu \mathrm{m}$ )

On the basis of The next step according to Sobrino and NDVI Raissouni (2000) is to calculate the fractional vegetation cover- $\mathrm{FVC}(\mathrm{Pv})$ :

$\mathrm{PV}=\left(\frac{\mathrm{NDVI}-\mathrm{NDVI}_{\min }}{\mathrm{NDVI}_{\max }-\mathrm{NDVI}_{\min }}\right)^{2}$

where $\mathrm{NDVI}_{\text {min }}$ and $\mathrm{NDVI}_{\text {max }}$ are the NDVI values for bare soil and full vegetation, respectively.

Further, emissivity for a full-vegetated land is counted on the basis of FVC. The most common way to calculate emissivity is a formula suggested by Sobrino and Raissouni (2000):

$\varepsilon=\varepsilon_{\mathrm{v}} P_{\mathrm{v}}+\varepsilon_{\mathrm{s}}\left(1-P_{\mathrm{v}}\right)+C$

where:

$P_{\mathrm{v}} \quad$ Fractional vegetation cover

$\varepsilon \quad$ Emissivity

$\varepsilon_{\mathrm{v}} \quad$ Emissivity for full-vegetated land $\varepsilon_{\mathrm{s}} \quad$ Emissivity for bare ground

C Cavity effect (for urban areas, this equals 0.005, according to Walawender 2009)

Radiation temperature, calculated from the thermal infrared remote sensing data, is a blackbody temperature whose emissivity $(\varepsilon)$ is 1 and its radiation temperature is equal to the surface temperature-LST. In the environmental sciences, the conception of "gray body" is defined because blackbody does not exist in the environment. Its emissivity is less than 1, making it necessary to use emissivity to calculate LST from the satellite data. By comparing the Stefan-Boltzmann law for a blackbody and gray body, it is possible to find a theoretical relationship between radiation temperature $\left(T_{\mathrm{R}}\right)$ and LST. The temperature of the surface is usually different from the LST counted on the basis of satellite data. The LST accuracy was validated for Landsat TM (sixth band) by Jiménez-Muñoz and Sobrino (2003). They showed that the root mean square deviation (RMSD) is lower than $1.5 \mathrm{~K}$ for different land cover types. On the basis of previous calculations, the LST can be counted using the following equation (Lillesand and Kiefer 2004):

$\mathrm{LST}=\frac{T_{\mathrm{R}}}{\varepsilon^{0.25}}$

where:

LST Land surface temperature [K]

$T_{\mathrm{R}} \quad$ Radiation temperature $[\mathrm{K}]$

$\varepsilon \quad$ Emissivity

Afterwards, the land surface temperature values can be converted from Kelvin to Celsius degrees. To do so, the following expression must be used:

$\mathrm{LST}_{\mathrm{C}}=\mathrm{LST}-273.15$

where:

$\mathrm{LST}_{\mathrm{C}} \quad$ Land surface temperature $\left[{ }^{\circ} \mathrm{C}\right]$

LST Land surface temperature [K]

A prediction of the air temperature $\left(T_{\mathrm{agl}}\right)$ directly from Landsat 5 TM data (LST) was realized via the standard statistical idea of constructing the best (fitted) regression model

$T_{\mathrm{agl}}=f(\mathrm{LST}, X, Y)+\xi$,

using the properly chosen function $f$ of independent variables LST and $X, Y$ describing the geographical location of measurement points, while $\xi$ denotes random error (with an expected value of 0 ). In order to select the best function $f$, a statistical analysis was performed for a combination of different (very wide) classes of functions (linear, non-linear, exponential, logarithmic, and hyperbolic including trigonometrical terms) in order to take into account the seasonal effect. Due to the 
relatively small number of observations $(n=120$, i.e., observations made in eight locations for 15 Landsat scenes-limiting numbers of parameters included in a model), the analyzed functions were classified into five groups (sets):

$$
\begin{aligned}
& f_{1}(\mathrm{LST}, X, Y)=P_{1}(\mathrm{LST}, X, Y)+A \\
& \times \sin \left[P_{2}(\text { LST }, X, Y)\right]+B \\
& \times \cos \left[P_{3}(\mathrm{LST}, X, Y)\right] \text {, } \\
& f_{2}(\mathrm{LST}, X, Y)=\frac{1}{P_{1}(\mathrm{LST}, X, Y)}+A \\
& \times \sin \left[P_{2}(\mathrm{LST}, X, Y)\right]+B \\
& \times \cos \left[P_{3}(\operatorname{LST}, X, Y)\right] \\
& f_{3}(\mathrm{LST}, X, Y)=\ln \left[P_{1}(\mathrm{LST}, X, Y)\right]+A \\
& \times \sin \left[P_{2}(\operatorname{LST}, X, Y)\right]+B \\
& \times \cos \left[P_{3}(\operatorname{LST}, X, Y)\right] \text {, } \\
& f_{4}(\mathrm{LST}, X, Y)=e^{P_{1}(\mathrm{LST}, X, Y)}+A \\
& \times \sin \left[P_{2}(\text { LST }, X, Y)\right]+B \\
& \times \cos \left[P_{3}(\mathrm{LST}, X, Y)\right] \text {, } \\
& f_{5}(\mathrm{LST}, X, Y)=e^{P_{1}(\mathrm{~L} \tilde{\mathrm{ST}}, X, Y)}+A \\
& \times \sin \left[P_{2}(\mathrm{LST}, X, Y)\right]+B \\
& \times \cos \left[P_{3}(\mathrm{LST}, X, Y)\right] \text {, }
\end{aligned}
$$

where:

$$
\begin{aligned}
& P_{h}(\mathrm{LST}, X, Y)=\sum_{i=0, j=0, k=0}^{4} b_{h i j k} \operatorname{LST}^{i} X^{j} Y^{k}, h \\
& \quad=1,2,3
\end{aligned}
$$

are independent selected polynomials of variables LST, $X, Y$, and $\mathrm{LS} T=\ln (\mathrm{LST})$ [logarithm of LST] that have (highest) degree 4 , where $\mathrm{LST}^{i}, X^{j}, Y^{j}$ mean the $i$ th power of LST, $j$ th power of $X$, and $k$ th power of $Y$, respectively.

Examples clarifying types of above polynomials are:

$$
\begin{aligned}
\text { for } h=1: & P_{1}(\mathrm{LST}, X, Y)=b_{1000}+b_{1100} \mathrm{LST}+ \\
& +b_{1200} \mathrm{LST}^{2} \\
\text { for } h=2: & P_{2}(\mathrm{LST}, X, Y)=b_{2000}+b_{2100} \mathrm{LST} \\
& +b_{2010} X+b_{2001} Y+b_{2011} X \times Y \\
\text { for } h=3: & P_{3}(\mathrm{LST}, X, Y)=b_{3000}+b_{3110} \mathrm{LST} \times X \\
& +b_{3101} \mathrm{LST} \times Y+b_{3111} \mathrm{LST} \times X \times Y,
\end{aligned}
$$

where $\mathrm{LST}^{2}$ means second power of LST, and coefficients $b_{h i j k}$ for other indices $i, j, k$ described in Eq. 13 and not used in above polynomials are equal to 0 .
Thus, the investigated models were of the form proposed by formula (8) using specific types of functions described in formulas (9-13):

$T_{\mathrm{agl}}=f_{i}(\mathrm{LST}, X, Y)+\xi, \quad i=1, \ldots, 5$

with the estimated coefficients $b_{h i j k}$ of the variables in polynomials defined by (14), as well as parameters $A$ and $B$, and under the assumption of normality in errors $\xi$. The estimation was performed using the standard least square method. It is important to underline that the geographical coordinates of measurement points (described by variables $X$ and $Y$ ) were also included in the model in order to determine their significance. In the procedure, a stepwise (backward) regression was used to determine:

1. If the prediction is dependent on the geographical location of measurement points at a statistically significant level

2. If the prediction is dependent on seasonal effects (measured by trigonometric terms with coefficients $A$ and $B$ ) at a statistically significant level

3. The possibility of reduction in the degree of polynomials $P_{1}, P_{2}$, and $P_{3}$ (according to Ockham's razor principle: Numquam ponenda est pluralitas sine necessitate-plurality must never be posited without necessity)

Models were constructed and estimated with the use of statistical package Statistica 10 (stepwise procedure was done partly manually due to complexity of the analyzed models and taking some of parameters $b_{h i j k}$ as equal to 0 in order to overcome the problem of overparametrization). The methodology described above is a generalization of methods (linear prediction) proposed by Kawashima et al. (2000) and Colombi et al. (2007). The idea was to construct a more advanced model that is valid for different times of the day and year while taking into account the location of measurement points. It should be noted that the above regression models are only an attempt to quantify the analyzed dependencies according to the limited possibilities of their verification due to difficulties with obtaining subsequent observations.

\section{Results}

\subsection{UHI on the basis of "in situ" data}

The city center is warmer than the surrounding area during most of the year (Półrolniczak et al. 2015). The average annual UHI intensity in the downtown area is $1.0{ }^{\circ} \mathrm{C}$ and decreases towards the periphery of the city along with a declining development intensity (Fig. 2). The intensity of the UHI was in general higher in the spring and summer seasons, even though it must be stated that extreme values may occur throughout the 


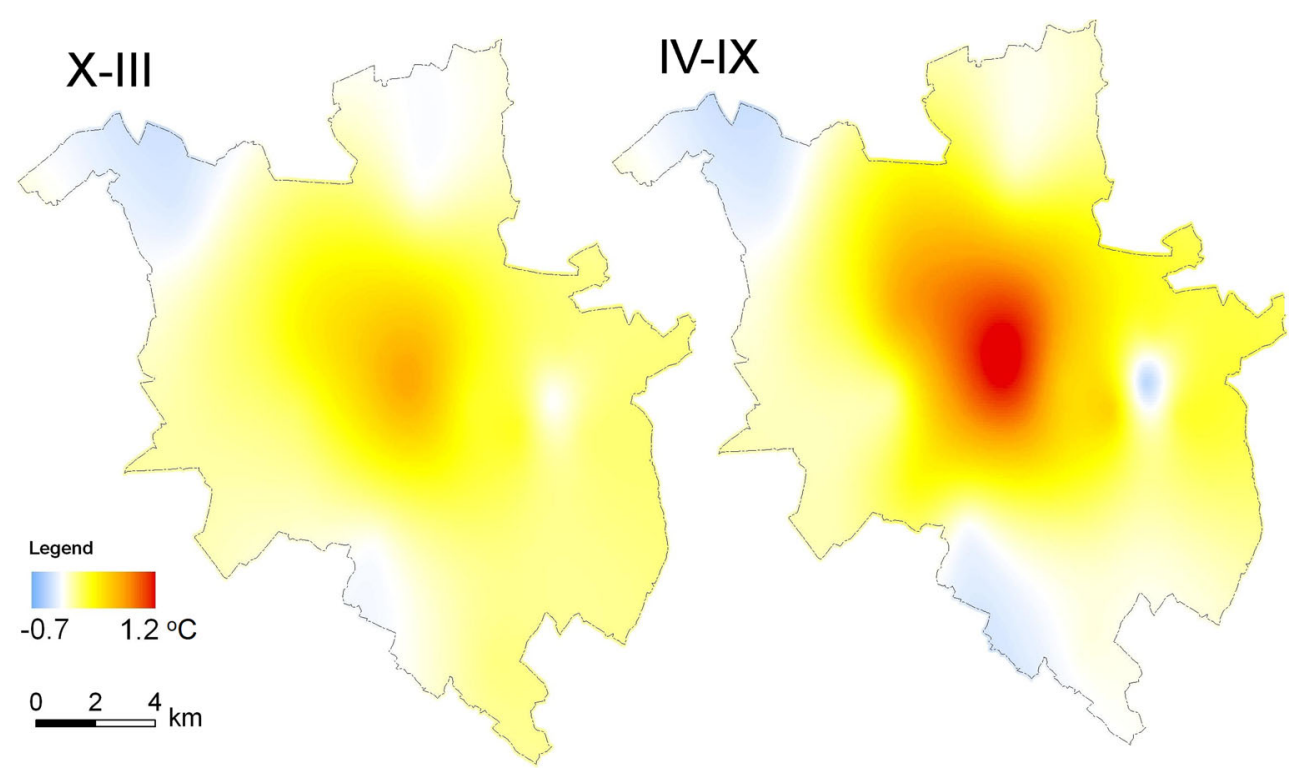

Fig. 2 The mean intensity of UHI in Poznań for a cold (X-III) and warm (IV-IX) part of the year. Data from the period June 2008-May 2013

year. For instance, the maximum intensity of the UHI (Piekary $7.0^{\circ} \mathrm{C}$ ) occurred on 26 January 2010 , with the second highest on 4 April 2009 (Collegium Minus $6.2^{\circ} \mathrm{C}$ ). As shown in Fig. 2, the spatial variability of mean UHI in Poznan for the period 2008-2013 takes usually the cellular form which is characterized by distinct foci on heat areas separated by cooler air. The UHI spatial differentiation in cold (X-III) and warm (IV-IX) seasons is similar to the warmest areas in the city center and the coldest in the outskirts, particularly in the eastern, northern, and northeastern regions. Spatial differentiation of the UHI is clearly correlated with the urban structures since the densely built-up downtown and areas with high buildings are much warmer than the urban green areas, water bodies, and their surroundings. Despite the similar spatial differentiation, the intensity of UHI is higher in the warm half of the year (Fig. 2).

Figure 3 shows the diurnal and annual UHI intensity in all the city's studied points. The predominant nocturnal nature of the UHI is evident especially in the city center (Fig. 3a, b) and in areas with high buildings (Fig. 3c). Higher values (more than $2{ }^{\circ} \mathrm{C}$ ) appear in 20-22 UTC from April to July in the city center (Fig. 3a), while smaller values (about $1.5^{\circ} \mathrm{C}$ ) may occur during the period from March to September in the afternoon (ca. 19 UTC). From March to August, the UHI intensity during daytime is about $1{ }^{\circ} \mathrm{C}$, and in April, it can reach $2{ }^{\circ} \mathrm{C}$ between 13 and 15 UTC (Fig. 3b). Areas with low buildings surrounded by urban green (Fig. $3 \mathrm{~g}$ ) have the highest values of UHI from the afternoon to the next morning mainly from March to May, while in the morning during the summer season, there is a so-called cold lake.

Generally, a smaller intensity as well as two maxima during the day are the characteristic features of the UHI in a compact single-family housing area (Fig. $3 \mathrm{~d}$ ). These maximum values reach above $0.5^{\circ} \mathrm{C}$ between 8 and $15 \mathrm{UTC}$ from February to September and from about 18 to 4 UTC from March to June.

In areas with a substantial share of green (Fig. 3e, f, h), the UHI occurs during the day with a peak in March and April (Fig. 3e, h), and at night, these areas get significantly cooler. The strong intensity of the "cold lake" appears in the evening and night for nearly most of the year, with a maximum in the summer between 19 and 23 UTC (Fig. 3e).

During daytime, the values of standard deviation for the mean UHI intensity vary from $0.51{ }^{\circ} \mathrm{C}$ (at Strzeszyn measurement point) to $0.73{ }^{\circ} \mathrm{C}$ (at Collegium Geographicum). At night, the standard deviation is higher and varies from $0.72{ }^{\circ} \mathrm{C}$ in Strzeszyn to $1.13{ }^{\circ} \mathrm{C}$ at Collegium Geographicum. The measurement point located in the city center - Piekary - is characterized by a standard deviation of $0.63{ }^{\circ} \mathrm{C}$ during the day and $0.82{ }^{\circ} \mathrm{C}$ at night.

\subsection{UHI on the basis of Landsat 5 TM data}

To characterize the spatial extent of the UHI in Poznań, a map of the mean land surface temperature anomalies was calculated (Fig. 4). This map was drawn up from the maximal number of available Landsat 5 TM data. In the case of Poznań, in a selected time period, there were 15 scenes from days with clear-sky conditions. The LST anomalies' map ( $\left.\mathrm{LST}_{\text {anom }}\right)$ was calculated as the difference between the mean map of LST derived from all 15 Landsat scenes $\left(\mathrm{LST}_{\mathrm{M} 15}\right)$ and the mean constant value of the $\mathrm{LST}_{\mathrm{M} 15}$ raster $\left(\mathrm{LST}_{\mathrm{ac}}\right.$ ), as shown in Eq. 15:

$\mathrm{LST}_{\text {anom }}=\mathrm{LST}_{\mathrm{M} 15}-\mathrm{LST}_{\mathrm{ac}}$.

The highest value of $\mathrm{LST}_{\text {anom }}$ is about $12.6^{\circ} \mathrm{C}$, and the lowest value reaches $-8.6{ }^{\circ} \mathrm{C}$. This points to the negative 

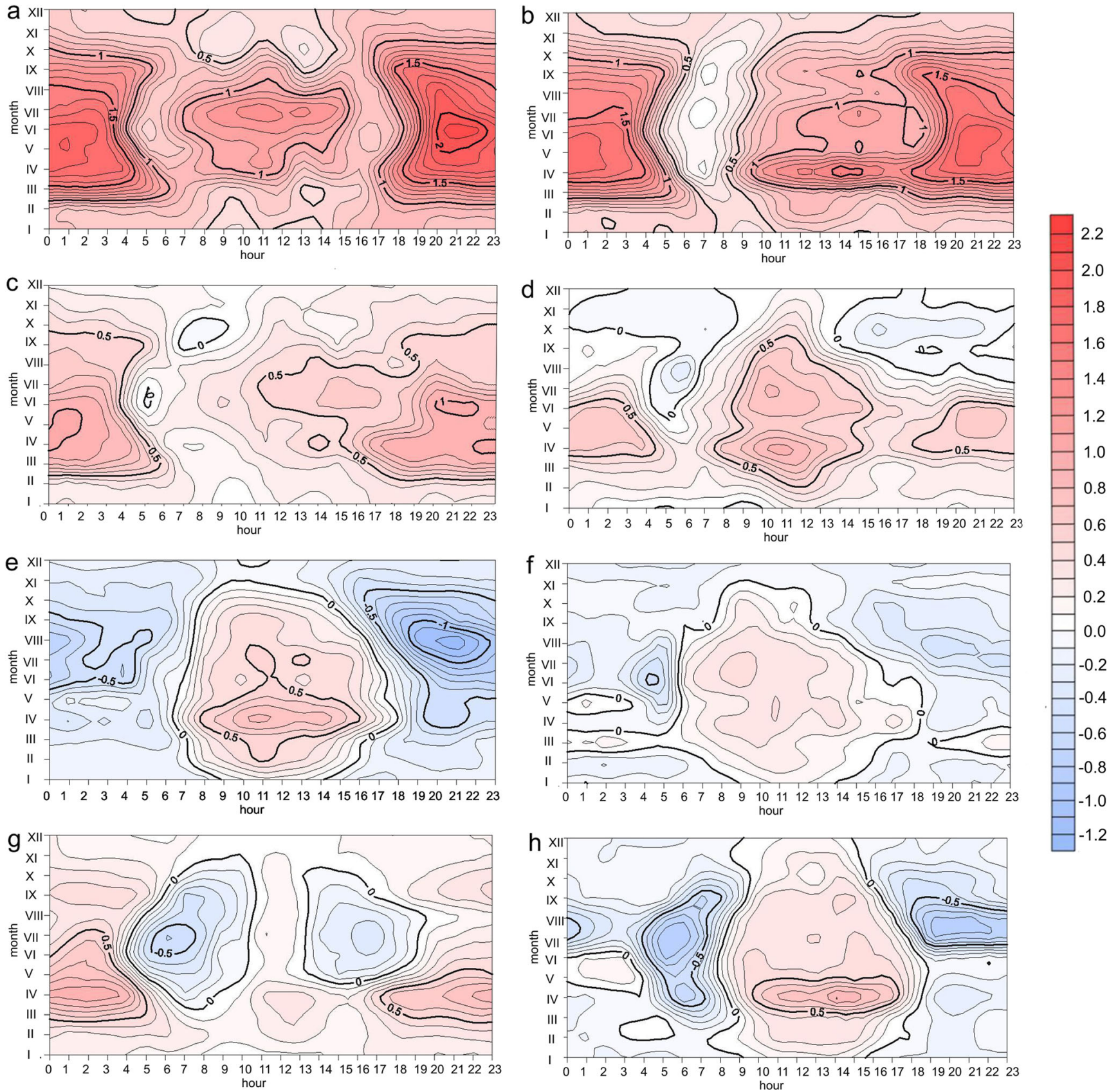

Fig. 3 Monthly and hourly mean intensity of UHI $\left({ }^{\circ} \mathrm{C}\right)$ in measurement points: Piekary $(\mathbf{a})$, Collegium Minus (b), Rusa (c), Świerczewo (d), Strzeszyn (e), Collegium Geographicum (f), Słoneczna (g), Dębina (h). Data from the period June 2008-May 2013

SUHI phenomenon. As can be seen from the map (Fig. 4), there is a noticeable difference between the urban fabric and green urban areas (parks, forests, arable land, etc.).

Selected land cover types were used to calculate the mean values of $\mathrm{LST}_{\text {anom. }}$ According to Corine Land Cover 2006, there are 12 different land cover types in Poznań (Table 2). The parameters presented in Table 2 were calculated with the ArcGIS 10.1 software using the Spatial Analyst Tools toolbox and function Zonal Statistics as Table. The highest values of mean LST anomalies have the following: continuous urban fabric $\left(3.4{ }^{\circ} \mathrm{C}\right)$, industrial or commercial units $\left(2.8^{\circ} \mathrm{C}\right)$, and airports $\left(2.2{ }^{\circ} \mathrm{C}\right)$. The lowest values have different types of forests such as broad-leaved forest $\left(-3.1^{\circ} \mathrm{C}\right)$, coniferous forest $\left(-2.9^{\circ} \mathrm{C}\right)$, and mixed forest $\left(-2.9^{\circ} \mathrm{C}\right)$. Between urbanized areas and forests, the average values of mean LST anomalies were reached by green urban areas, arable land, pastures, sport facilities, and discontinuous urban fabric. The mean maximum LST anomalies $\left(12.0^{\circ} \mathrm{C}\right)$ are placed within industrial or commercial units, while the minimum for mixed forest is $-0.7^{\circ} \mathrm{C}$.

The outcome from Table 2, in terms of green urban and various types of forest areas, should be discussed. The $T_{\text {anom }}$ 


\section{Legend}
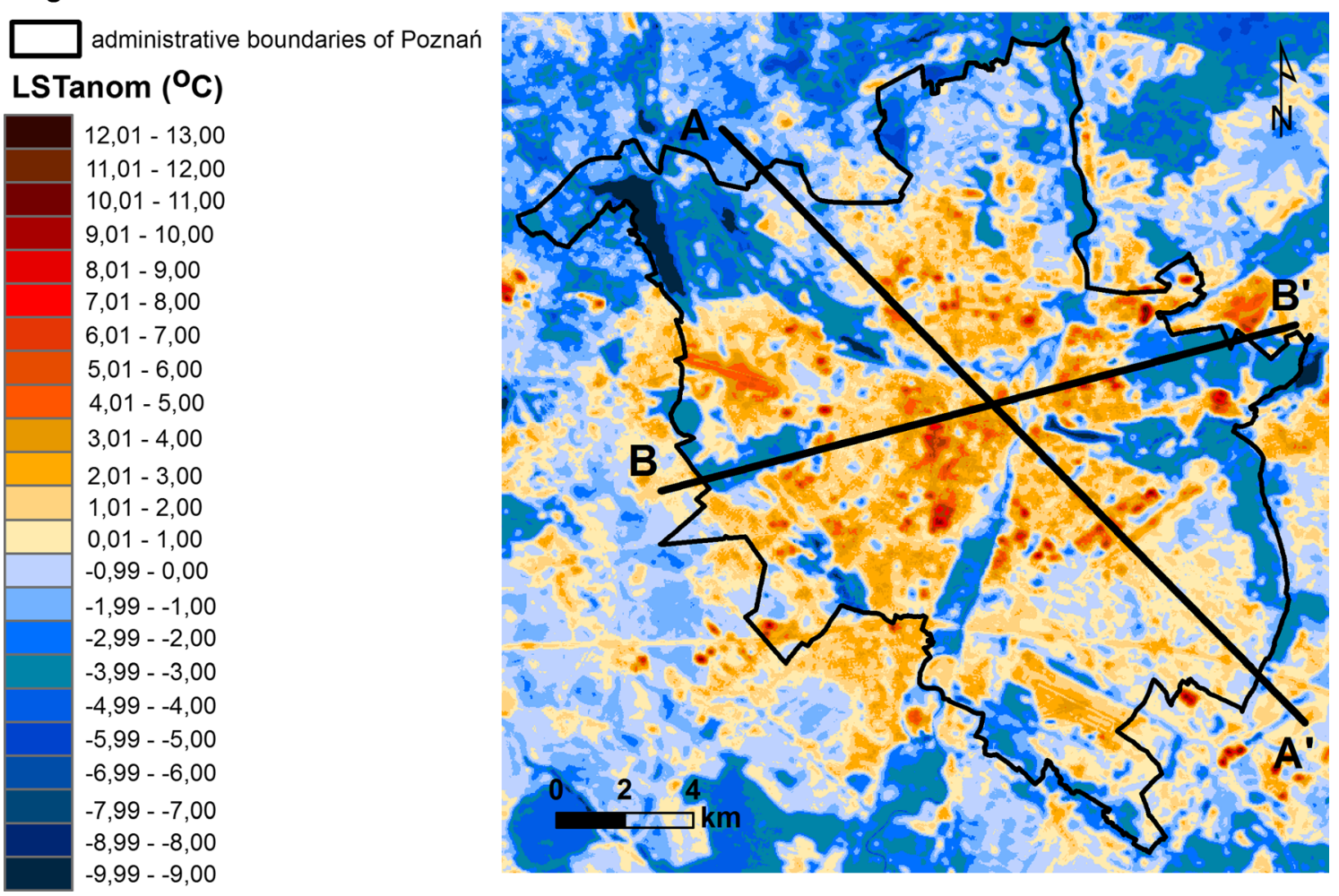

Fig. 4 Spatial variability of $\operatorname{LST}_{\text {anom }}\left({ }^{\circ} \mathrm{C}\right)$ in Poznań and profile lines used in Fig. $5\left(A-A^{\prime}\right)$ and Fig. $6\left(B-B^{\prime}\right)$

values presented below are differences of air temperature obtained from the statistical model based on Landsat and in situ measurement data (as shown in Eq. 14) and constant territorial average air temperature for entire city in its administrative boundaries. In contrast to other land cover types, the $T_{\text {anom }}$ values are equal to or higher than that of the LST. The overestimation of model temperature values in relation to the $\mathrm{LST}_{\mathrm{M} 15}$ for green areas is probably caused by a differentiation of the structure of energy balance for different types of surface (Oke 1988; Paszyński et al. 1999; Arnfield 2003). Moreover, researchers have decided to use a univariate regression model in terms of different surface types, which may incorporate additional bias due to the uneven weight provided by specific land use categories.

The mean difference between the measured air temperature at $2 \mathrm{~m}$ a.g.l. and the mean temperature of every pixel value

Table 2 Mean, minimum, maximum, and standard deviation of $\mathrm{LST}_{\text {anom }}$ and $T_{\text {anom }}\left({ }^{\circ} \mathrm{C}\right)$ for individual land cover types

\begin{tabular}{|c|c|c|c|c|c|c|}
\hline \multirow[t]{2}{*}{ Land cover } & \multirow[t]{2}{*}{ Pixel count } & \multirow[t]{2}{*}{ Area (ha) } & \multicolumn{4}{|c|}{$\mathrm{LST}_{\text {anom }} / T_{\text {anom }}\left({ }^{\circ} \mathrm{C}\right)$} \\
\hline & & & Mean & Min & Max & STD \\
\hline Continuous urban fabric & 220 & 22.0 & $3.38 / 2.50$ & $0.47 / 0.35$ & $5.57 / 4.12$ & $0.9 / 0.6$ \\
\hline Discontinuous urban fabric & 7835 & 783.5 & $1.54 / 1.14$ & $-5.19 /-3.80$ & $9.34 / 6.93$ & $1.3 / 1.0$ \\
\hline Industrial or commercial units & 1630 & 163.0 & $2.83 / 2.10$ & $-3.70 /-2.72$ & $12.0 / 8.90$ & $2.1 / 1.5$ \\
\hline Airports & 785 & 78.5 & $2.20 / 1.63$ & $-3.20 /-2.35$ & $5.50 / 7.16$ & $1.5 / 1.1$ \\
\hline Green urban areas & 911 & 91.1 & $-1.38 /-1.00$ & $-4.25 /-3.12$ & $4.50 / 3.33$ & $2.0 / 1.5$ \\
\hline Sport and leisure facilities & 2208 & 220.8 & $-0.49 /-0.35$ & $-6.08 /-4.50$ & $6.03 / 4.50$ & $1.8 / 1.3$ \\
\hline Non-irrigated arable land & 5021 & 502.1 & $-0.27 /-0.19$ & $-5.72 /-4.20$ & $8.97 / 6.65$ & $1.2 / 0.9$ \\
\hline Pastures & 1432 & 143.2 & $-1.09 /-0.80$ & $-5.68 /-4.16$ & $3.82 / 2.83$ & $1.5 / 1.1$ \\
\hline Complex cultivation patterns & 946 & 94.6 & $-0.19 /-0.14$ & $-5.30 /-3.89$ & $4.43 / 3.28$ & $1.7 / 1.2$ \\
\hline Broad-leaved forest & 1517 & 151.7 & $-3.07 /-2.25$ & $-5.48 /-4.01$ & $1.82 / 1.35$ & $1.0 / 0.8$ \\
\hline Coniferous forest & 1353 & 135.3 & $-2.89 /-2.12$ & $-5.21 /-3.82$ & $1.92 / 1.43$ & $0.9 / 0.7$ \\
\hline Mixed forest & 808 & 80.8 & $-2.93 /-2.15$ & $-5.88 /-4.32$ & $-0.70 / 1.87$ & $1.3 / 0.9$ \\
\hline
\end{tabular}


$(30 \times 30 \mathrm{~m})\left(\mathrm{LST}_{\mathrm{M} 15}\right)$ is significantly higher for urbanized areas (as shown later in Fig. 7). In urbanized areas, a particular pixel is characterized by a more irregular type of surface. The surface configuration (roughness, geometry, albedo, etc.) has an impact on the temperature inside every pixel, which strongly modifies the obtained results. The results shown in Table 2 indicate an overestimation by the model $T_{\text {agl }}$ for green urban areas and perhaps an underestimation in others. The obtained results show that the construction of a univariate model for calculating $T_{\mathrm{agl}}$ on the basis of LST in urban areas is very difficult.

To characterize in detail the spatial extent of the surface urban heat island in Poznań, two profile graphs were made (Fig. 4). Profile A-A' crosses the city from the north-west to south-east (Fig. 5). The mean $\mathrm{LST}_{\text {anom }}$ for the entire profile is $0.8{ }^{\circ} \mathrm{C}$. The maximum reaches $5.8^{\circ} \mathrm{C}$ and the minimum $-2.7^{\circ} \mathrm{C}$. The range of $\mathrm{LST}_{\text {anom }}$ in profile A-A' is $8.5^{\circ} \mathrm{C}$. To create this graph, 814 raster cells were used, which gives the distance between the start and end point at about $24 \mathrm{~km}$. The $\mathrm{LST}_{\text {anom }}$ values vary, depending on the type of land use. Profile A-A' starts at the northwestern suburbs of Poznań, where the dominant land cover types are arable land, small housing estates, and forests. Then, the profile crosses through a green urban area known as the western wedge. In this area, the minimum $\mathrm{LST}_{\text {anom }}$ is reached. Then, the profile $\mathrm{A}-\mathrm{A}^{\prime}$ crosses the warmer part of Poznań-the city center. Afterwards, the profile cuts through the Warta River valley, housing estate and retail park, where the maximum $\mathrm{LST}_{\text {anom }}$ values are reached before heading to the southeastern borders of Poznań where $\mathrm{LST}_{\text {anom }}$ sharply decreases. As can be seen from profile $\mathrm{A}-\mathrm{A}^{\prime}$, the southeastern suburbs are warmer than the north-western's and is caused by the industrial character of the area.
Profile graph B-B' crosses Poznań from west to east (Fig. 6). The mean $\mathrm{LST}_{\text {anom }}$ for the whole profile is $0.19{ }^{\circ} \mathrm{C}$, with a maximum of $6.6^{\circ} \mathrm{C}$ and a minimum of $-4.3{ }^{\circ} \mathrm{C}$. The B-B' profile consists of 661 raster cells (about $20 \mathrm{~km}$ ), and begins in the western suburbs of Poznań (mainly arable lands and discontinuous urban fabric). As can be seen in the profile graph, there are 5 rapid $\mathrm{LST}_{\mathrm{anom}}$ drops. These drops are respectively caused by forests and allotment gardens in northern part of the eastern wedge of the green area. The warmest areas are found in the Poznań International Fair, main railway station, and continuous urban fabric in the city center. The increase in $\mathrm{LST}_{\text {anom }}$ in the eastern suburbs is caused by the industrial and residential character of the surrounding district.

\subsection{UHI on the basis of regression models}

One of the simplest solutions for predicting $T_{\mathrm{agl}}$ on the basis of LST is the linear regression approach, using the least squares method for estimating the regressions' coefficients:

$\hat{T}_{\mathrm{agl}}=a \times \mathrm{LST}+b$

where:

$T_{\text {agl }} \quad$ Predicted $T_{\text {agl }}$ on the basis of LST

$a, b \quad$ Linear regression coefficients (slope and intercept, respectively)

The results from the linear models in terms of predicting


$\left(r^{2}\right)$ values varies from 0.78 (Lawica-airport) to 0.90 (Dębina) and for all measurement points (total) $r^{2}=0.77$.

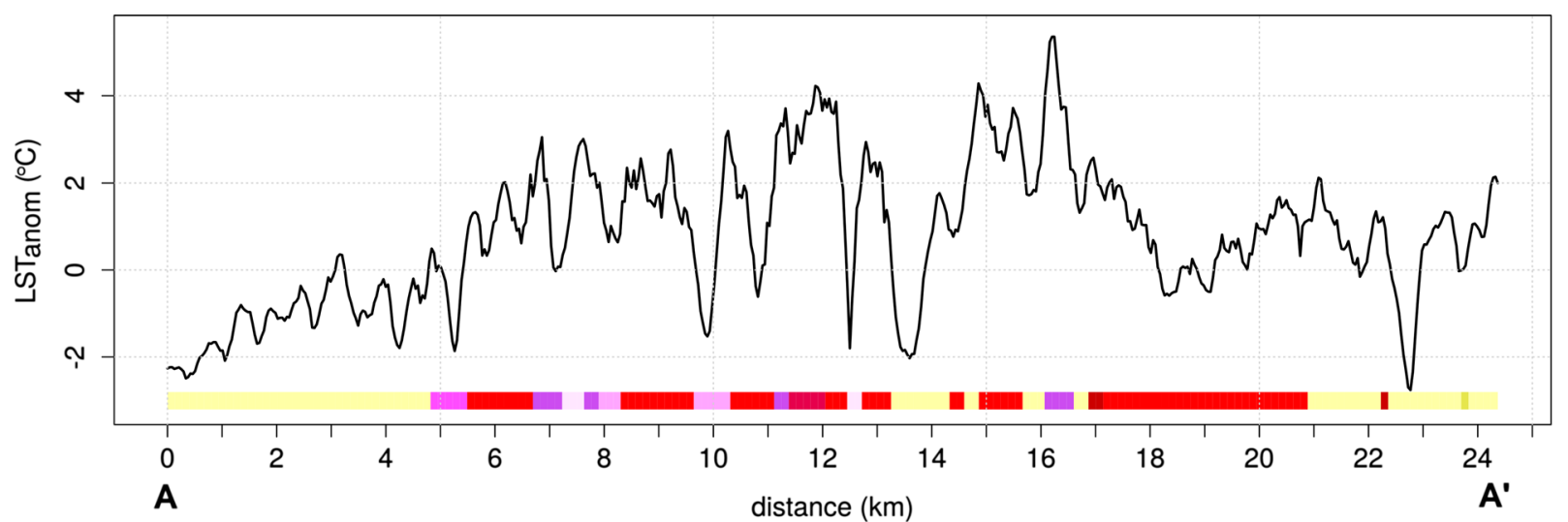

\section{Legend}

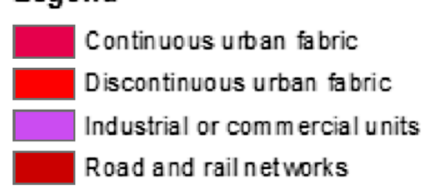

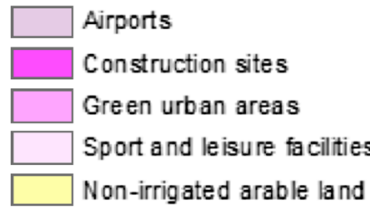

( $\mathrm{km})$

Fig. 5 ( $A-A^{\prime}$ Profile graph of $\mathrm{LST}_{\text {anom }}\left({ }^{\circ} \mathrm{C}\right)$ on the background of Corine Land Cover 2006 


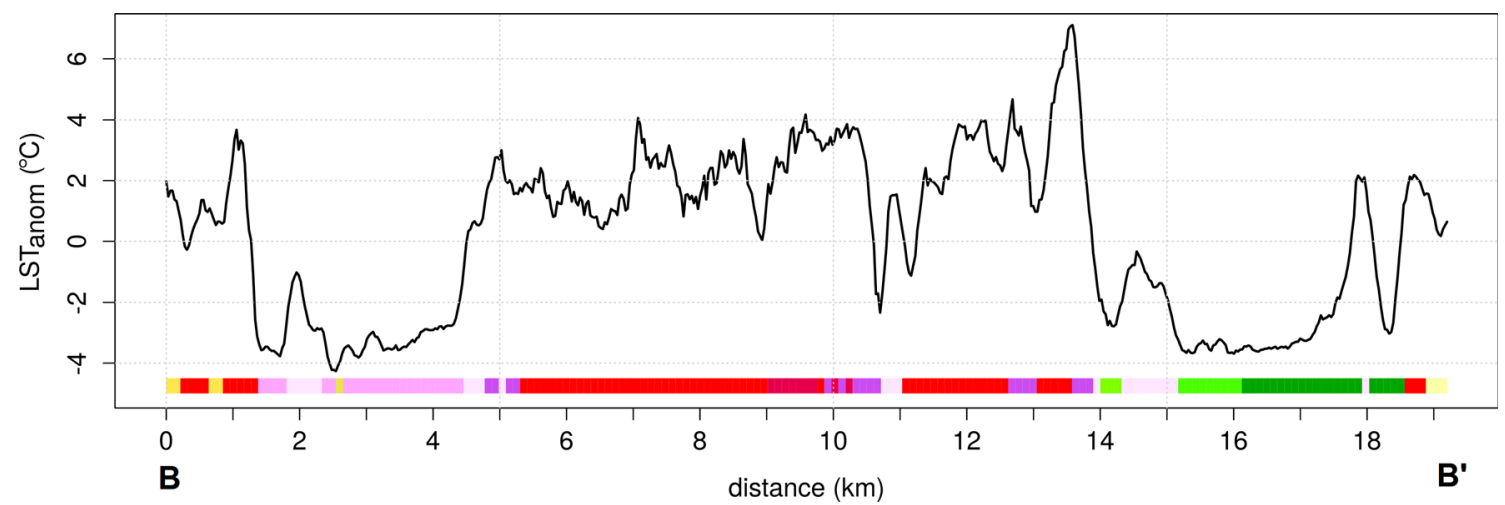

Fig. $6 B-B^{\prime}$ Profile graph of $\operatorname{LST}_{\text {anom }}\left({ }^{\circ} \mathrm{C}\right)$ on the background of Corine Land Cover 2006 (used colors denoting land use types same as in Fig. 5)

However, the residuals for all types of land uses seem to have a very high range (in some cases beyond $10{ }^{\circ} \mathrm{C}$, Fig. 8).

In the next part of the study, an attempt to improve the obtained results was made by means of the non-linear regression model. The best function to forecast air temperature turned out to be the regression model based on the function $f_{5}$ with the polynomial $P_{1}$ ((L) T T, $\left.X, Y\right)$ of the degree 1 (being the linear function of the logarithm of LST), independent statistically in trigonomical terms. It could be presented in the form:

$T_{\mathrm{agl}}=b_{0} \times(\mathrm{LST})^{\boldsymbol{b}_{1}}$

where:

LST Land surface temperature $\left[{ }^{\circ} \mathrm{C}\right]$

$b_{0}$, Coefficients of the regression model

$b_{1}$

$T_{\text {agl }} \quad$ Estimated air temperature $2 \mathrm{~m}$ above ground level

$\left[{ }^{\circ} \mathrm{C}\right]$
The prediction is independent of the location of the measurement point.

The results procured on the basis of the above type of function are sufficiently reliable. The reduced final model is built with the use of 120 observations which, for such a linearized one variable model, constitute a sufficient sample size (Kelley and Maxwell 2003; Soper 2015). It is confirmed by a relatively high value of coefficient of determination $\left(r^{2}=0.84\right)$. The estimated parameters of the regression model are presented in Table 3.

Presented below (Fig. 8) is the distribution of residuals ( $\Delta T=T_{\mathrm{agl}}-T_{\mathrm{agl}}$ ) of the estimated models which confirms their expected normality. It is worth noticing that the obtained residuals for the non-linear model are slightly better fitted in comparison to the linear assumption.

As a result of the presented statistical non-linear model, the mean map of air temperature anomalies was calculated $\left(T_{\text {anom }}\right.$, Fig. 9). This map is calculated from the $\mathrm{LST}_{\mathrm{M} 15}$ map as the difference between the mean map of $T_{\mathrm{agl}}$ and the city area


Land Surface Temperature (LST) $\left[{ }^{\circ} \mathrm{C}\right]$

Fig. 7 Scatterplots of LST and corresponding air temperature at $2 \mathrm{~m}$ height. $\Delta T$ denotes the mean difference between LST and $T_{\mathrm{agl}}$. Gray area indicates $95 \%$ confident interval for linear assumption. 


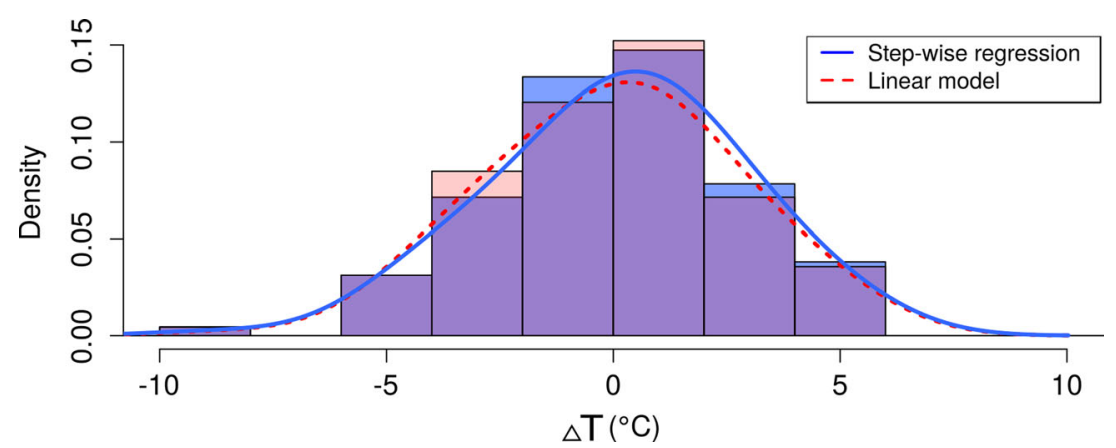

Fig. 8 Distribution of residuals for the estimated models: non-linear regression model (blue line and blue stripes) and linear model (red dashed line and red stripes)

mean value of $T_{\mathrm{ag} 1}$ (constant value). The maximum of the mean air temperature anomaly $\left(T_{\text {anom }}\right)$ reaches almost $9.4{ }^{\circ} \mathrm{C}$, while the minimum equals $-6.3^{\circ} \mathrm{C}$. Within the measurement points, the highest values of received $T_{\text {anom }}$ can be found in Lawica $\left(3.4^{\circ} \mathrm{C}\right.$ ), Piekary $\left(2.2^{\circ} \mathrm{C}\right)$, and Świerczewo $\left(2.0^{\circ} \mathrm{C}\right)$. The lowest values are achieved in measurement points Dębina $\left(-0.9^{\circ} \mathrm{C}\right)$ and Słoneczna $\left(-0.6{ }^{\circ} \mathrm{C}\right)$.

\section{Discussion and conclusions}

In situ measurements clearly show that the UHI phenomenon is a common occurrence in the city of Poznan (Półrolniczak et al. 2015). The mean annual intensity of UHI reaches $1.0^{\circ} \mathrm{C}$, while the intensity of UHI is greater in the warm half of the year than in the cold one. Analyzing the diurnal course, the highest intensity of UHI is reached between 20 and 22 UTC from April to July in the city center (above $2{ }^{\circ} \mathrm{C}$ in average). This is despite the fact that at night, the city center is clearly warmer than the peripherals. The coldest times during the day in the center of Poznań are between 5 and 7 UTC. The UHI intensity reaches its minimum values of 0.5 to $0.7{ }^{\circ} \mathrm{C}$-in comparison to Ławica (airport) station. Cold lakes (i.e., situations with air temperature being higher at the airport) appear beyond the city center during night hours, mainly in areas with low urban development, with a maximum intensity below $-1{ }^{\circ} \mathrm{C}$ in Strzeszyn station. Both the maximal intensity and cold lake situations are mostly observed during the warm season of the year (Półrolniczak et al. 2015). These features of UHI were also found by other researchers worldwide (e.g., Arnfield 2003; Zhang et al. 2014) and confirm the regularities of the annual and diurnal course of this phenomenon found in other Polish cities (Szymanowski 2004; Bokwa 2010).

The SUHI in Poznań based on LST derived from Landsat 5 TM imageries show differences for particular land cover categories. Continuous urban fabric and industrial and commercial units are the warmest categories and constitute the hot spots in the area of Poznań. A slightly lower LST characterizes areas with lower urban development, while the coolest are green urban areas, sport and leisure facilities, or pastures and forests. The biggest difference in $\mathrm{LST}_{\text {anom }}$ for selected land covers reaches $6.45{ }^{\circ} \mathrm{C}$ (difference between the mean $\mathrm{LST}_{\text {anom }}$ for continuous urban fabric and broad-leaved forests), even though the differences between the hottest and coolest pixels ( $\left.\mathrm{LST}_{\mathrm{M} 15}\right)$ could be considered greater and can reach as high as $21.2^{\circ} \mathrm{C}$.

To calculate the air temperature $\left(T_{\mathrm{agl}}\right)$ from Landsat $5 \mathrm{TM}$ data, both linear and non-linear regression models were applied. Slightly better results were obtained from the non-linear regression model, which are confirmed by a slightly higher value of coefficient of determination $\left(r^{2}=0.84\right)$ and normally distributed residuals.

For the areas represented by the highest degree of urbanization (continuous urban fabric and industrial and commercial units), $T_{\text {anom }}$ is equal to 2.5 and $2.1^{\circ} \mathrm{C}$ respectively. The same order of magnitude is recognized for the coolest areas (forests), where the minimum equals $-2.2{ }^{\circ} \mathrm{C}$. The biggest difference between the mean $T_{\text {anom }}$ values concerning various types of land cover is $4.7^{\circ} \mathrm{C}$ and is lower than the LST one (the difference between the mean $T_{\text {anom }}$ for continuous urban fabric and broad-leaved forests). Similarly, the maximum difference concerning the hottest and coolest pixels on $T_{\mathrm{agl}}$ is lower than that on the LST map, which is about $15.7^{\circ} \mathrm{C}$.
Table 3 Estimated parameters of the model

\begin{tabular}{llllll}
\hline Coefficients & Estimators & Standard deviation & $P$ value & \multicolumn{2}{l}{$95 \%$ confidence interval $(\mathrm{CI})^{\mathrm{a}}$} \\
\cline { 5 - 5 } & & & & CI_L lower endpoint & CI_U upper endpoint \\
\hline b0 & 0.633 & 1.148 & 0.002262 & 0.470 & 0.844 \\
b1 & 1.035 & 0.044 & 0.000001 & 0.948 & 1.121 \\
\hline
\end{tabular}

${ }^{\text {a }} 95 \%$ confidence interval: $\operatorname{Pr}\left(\mathrm{CI} \_\right.$L $<$LST $<$CI_U $\left.)=0.95\right)$, Pr, probability 
Legend
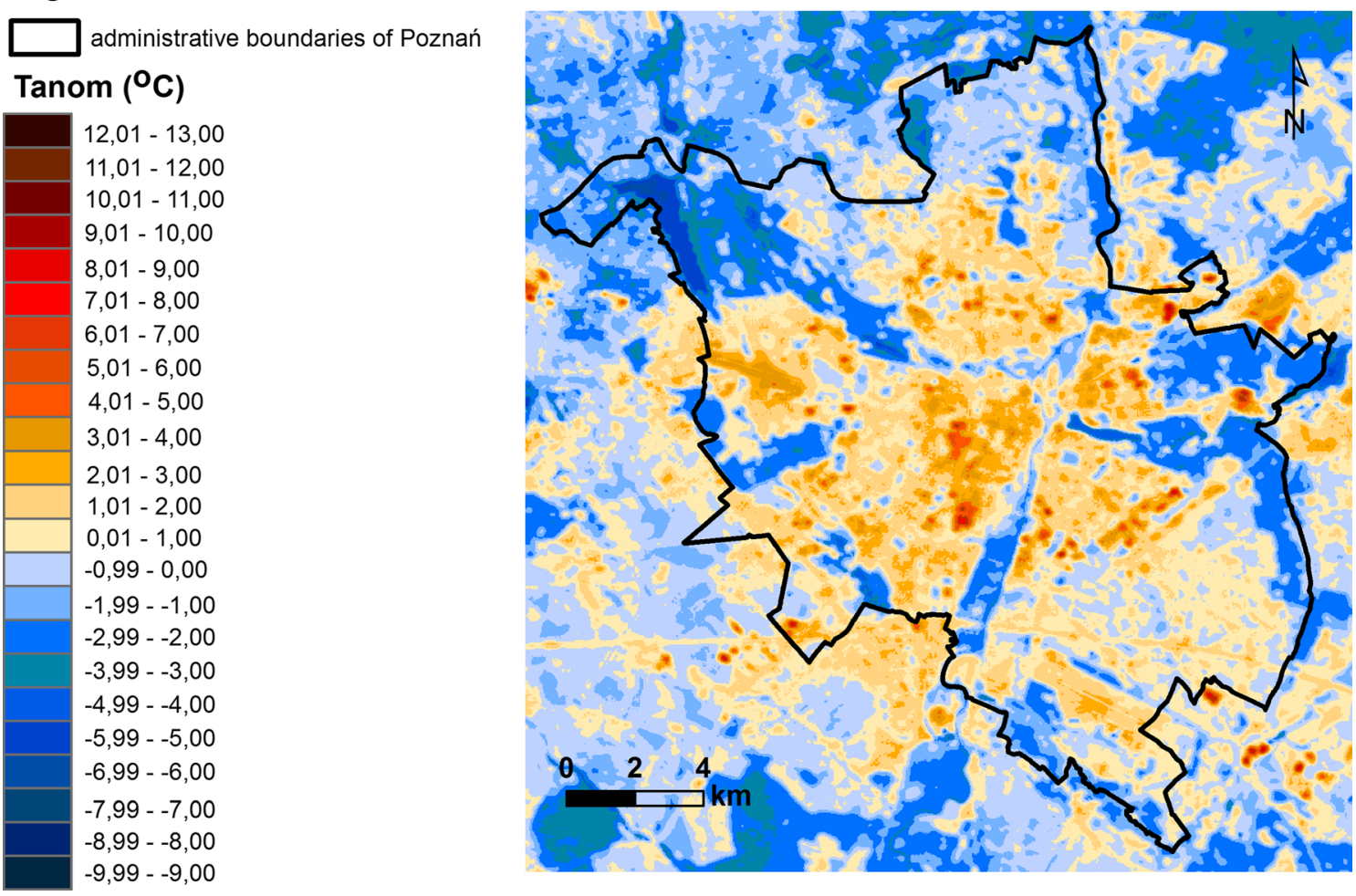

Fig. 9 Spatial variability of $T_{\text {anom }}\left({ }^{\circ} \mathrm{C}\right)$ in Poznań. Values calculated using non-linear regression model

Even if applying a simple statistical model does not allow for treating the obtained air temperature equally with traditional in situ measurements, it is robust enough to indicate areas of hot spots and cold lakes with a resolution of raster cell size (for Landsat $5 \mathrm{TM}$, it is equal to $30 \times 30 \mathrm{~m}$ ). These small-scale details might often be diminished (or completely omitted) while using a traditional coarse in situ measurement network. However, simplistic statistical models are reported to perform not so well in the case of neural networks or even more expanded multiple regression analyses and may lead to considerable biases for heads and tails of distributions (Fig. 7). The source of the problems is related to possible LST estimation errors (Schwarz et al. 2011), in terms of high complexity of land use types in a city. Different types of surfaces may strongly vary in terms of thermal capacity (Wloczyk et al. 2011), which means that a single universal regression model applied to an entire city may have problems with extreme values. This is despite the fact that the obtained accuracies for linear and non-linear models are similar to other models applied in similar research. For instance, Utsunomiya (1992), using the in situ measurements and Landsat 5 TM data, constructed a linear model that allows for calculating air temperature on Kyushu Island. On the basis of 51 samples, the accuracy of the model as given by the coefficient of determination was equal to 0.80 , while in the case of Poznań wherein 15 imageries were used, the accuracy was slightly higher (0.84). In a study conducted by
Wloczyk et al. (2011) based on Landsat 7ETM+ for more homogenous green areas, the coefficients of determination were slightly higher $\left(r^{2}=0.89\right)$, with an average root mean square error of about $3 \mathrm{~K}$. The same order of accuracy was obtained in a research based on MODIS thermal products conducted by Sun et al. (2005), wherein over $80 \%$ of the analyzed samples had an accuracy of $3 \mathrm{~K}$. A strong relationship between LST (derived from Landsat TM) and air temperature was also found in a recent study by Martin et al. (2015) for Montreal and by Klok et al. (2012) for Rotterdam, which obtained coefficients of determination of up to 0.81 .

In every aforementioned example, the coefficients of determination are relatively high and comparative with values obtained in this study, even though in all cases there is a possibility of elevated biases in connection with a very complex structure of land use in the city (e.g., urban fabric, land cover, topography, etc.). Nevertheless, based on coupling both in situ and thermal remote sensing data, the calculated fields allow for characterizing UHI and SUHI spatial variability to an extent greater than using only one source of information.

Acknowledgments The authors wish to express their thanks to a referee for bringing their attention to works connected with the analyzed problem. The advices and comments made by referees have been great help in the preparation of the final corrected and improved version of this paper. 
Open Access This article is distributed under the terms of the Creative Commons Attribution 4.0 International License (http:// creativecommons.org/licenses/by/4.0/), which permits unrestricted use, distribution, and reproduction in any medium, provided you give appropriate credit to the original author(s) and the source, provide a link to the Creative Commons license, and indicate if changes were made.

\section{References}

Arnfield AJ (2003) Two decades of urban climate research: a review of turbulence, exchanges of energy and water, and the urban heat island. Int J Climatol 23:1-26. doi:10.1002/joc.859

Bechtel B, Zakšek K, Hoshyaripour G (2012) Downscaling land surface temperature in an urban area: a case study for Hamburg. Germany, Remote Sensing 4:3184-3200. doi:10.3390/rs4103184

Bokwa A (2010) Wieloletnie zmiany struktury mezoklimatu miasta na przykładzie Krakowa (Multi-annual changes of the urban mesoclimate structure (using an example of Kraków)). IGiGP, Kraków, Wyd. UJ

Chander G, Markham B (2003) Revised Landsat-5 TM radiometric calibration procedures and postcalibration dynamic ranges. IEEE Trans Geosci Remote Sens 41:2674-2677

Childs C. (2004), Interpolating surfaces in ArcGIS spatial analyst, ArcUser, July-September 32-35

Central Statistical Office (2012) Statistical yearbook of the Republic of Poland, http://old.stat.gov.pl/gus/5840_2844_ENG_HTML.htm. Accessed 23 July 2013

Colombi A, De Michele C, Pepe M, Rampini A (2007) Estimation of daily mean air temperature from MODIS LST in Alpine areas. EARSeL eProceedings 6:38-46

Corine Land Cover (2006), http://www.eea.europa.eu. Accessed 10 November 2013

Dobrovolny P (2013) The surface urban heat island in the city of Brno (Czech Republic) derived from land surface temperatures and selected reasons for its spatial variability. Theor Appl Climatol 112: 89-98. doi:10.1007/s00704-012-0717-8

Dousset B, Gourmelon F (2003) Satellite multi-sensor data analysis of urban surface temperatures and land cover. ISPRS J Photogrametry Remote Sensing 58:43-54. doi:10.1016/S0924-2716(03)00016-9

Fabrizi R, Bonafoni S, Biondi R (2010) Satellite and ground-based sensors for the urban heat island analysis in the city of Rome. Remote Sens 2:1400-1415. doi:10.3390/rs2051400

Fabrizi R., De Santis A., Gomez A. (2011) Satellite and ground-based sensors for the urban heat island analysis in the city of Madrid. Urban Remote Sensing Event, 349-352, doi: 10.1109/ JURSE.2011.5764791

Fortuniak K, Kłysik K (2008) Singularities of urban climate— Lódź case study. In: Kłysik K, Wibig J, Fortuniak K (eds) Klimat i bioklimat miast (Climate and bioclimate of cities). Wyd. UŁ, Łódź, pp 477488

Jauregui E (1997) Heat island development in Mexico City. Atmos Environ 31:3821-3831. doi:10.1016/S1352-2310(97)00136-2

Jiménez-Muñoz JC, Sobrino JA (2003) A generalized single-channel method for retrieving land surface temperature form remote sensing data. J Geophys Res 108(D22):4688. doi:10.1029/ 2003JD003480

Kaszewski BM, Siwek K (1998) Cechy przebiegu dobowego temperatury powietrza $\mathrm{w}$ centrum i na peryferiach Lublina (Features the course of daily air temperature in the center and on the outskirts of Lublin, Acta Universitatis Lodziensis). Folia Geographica Physica 3:213-220
Kawashima S, Ishida T, Minomura M, Miwa T (2000) Relations between surface temperature and air temperature on a local scale during winter nights. J Appl Meteorol 39:1570-1579

Kelley K, Maxwell SE (2003) Sample size for multiple regression: obtaining regression coefficients that are accurate, not simply significant. Psychol Methods 8(3):305-321. doi:10.1037/1082-989X. 8.3.305

Klok L, Zwart S, Verhagen H, Mauri E (2012) The surface heat island of Rotterdam and its relationship with urban surface characteristics. Resour Conserv Recycl 64:23-29

Kłysik K, Fortuniak K (1999) Temporal and spatial characteristics of the urban heat island of Łódź. Poland Atmospheric Environ 33:38853895

Koczorowska R, Farat R (2006) Specyfika warunków termicznych i wiatrowych aglomeracji poznańskiej (The specificity of thermal and wind condition of Poznań agglomeration). IMGW, Poznań

Kondracki J (2002) Geografia regionalna Polski (Regional geography of Poland). Wydawnictwo Naukowe PWN, Warszawa

Landsberg HE (1981) The urban climate, vol 285. Academic Press, Md, USA

Lillesand TM, Kiefer RW (2004) Remote sensing and image interpretation. Wiley, Toronto

Magee N, Curtis J, Wendler G (1999) The urban heat island effect at Fairbanks. Alaska Theoretical Applied Climatol 64:39-47. doi:10. 1002/joc. 971

Martin P, Baudouin Y, Gachon P (2015) An alternative method to characterize the surface urban heat island. Int J Biometeorol 59:849-861. doi:10.1007/s00484-014-0902-9

Montavez JP, Jimenes JI, Sarsa A (2000) A Monte Carlo model of the nocturnal surface temperatures in urban canyons. Bound-Lay Meteorol 96:433-452. doi:10.1023/A:1002600523841

Morris CJG, Simmonds I (2000) Associations between varying magnitudes of the urban heat island and the synoptic climatology in Melbourne. Australia Int J Climatol 20:1931-1954

Morris CJG, Simmonds I, Plummer N (2001) Quantification of the influences of wind and cloud on the nocturnal urban heat island of a large city. J Appl Meteorol Climatol 40:169-182. doi:10.1175/15200450(2001)0402.0.CO;2

Oke TR (1973) City size and the urban heat island. Atmos Environ 7: 769-779

Oke TR (1976) The distinction between canopy and boundary-layer urban heat islands. Atmosphere 14:268-277

Oke T. R. (1979) Technical note no. 169: review of urban climatology. World Meteorological Organization: Geneva, Switzerland, p. 43

Oke TR (1982) The energetic basis of the urban heat island. Q J Roy Meteorol Soc 108:1-24

Oke TR (1988) The urban energy balance. Prog Phys Geogr 12:471-508

Paszyński J, Miara K, Skoczek J (1999) The energy exchange at the earth-atmosphere boundary as a base of topoclimatological classification, Dokumentacja Geograficzna 14. IGiPZ PAN, Warszawa, pp 57-61

Philandras CM, Metaxas DA, Nastos PT (1999) Climate variability and urbanization in Athens. Theor Appl Climatol 63:65-72

Półrolniczak M., Kolendowicz L., Majkowska A., Czernecki B. (2015) The influence of atmospheric circulation on the intensity of urban heat island and urban cold island in Poznań, Poland. Theoretical and Applied Climatology, doi: 10.1007/s00704-015-1654-0

Rao PK (1972) Remote sensing of urban heat islands from an environmental satellite. Bull Am Meteorol Soc 53:647-648

Ripley EA, Archibold OW, Bretell DL (1996) Temporal and spatial temperature patterns in Saskatoon. Weather 51:398-405. doi:10.1002/j. 1477-8696.1996.tb06171.x

Schwarz N, Lautenbach S, Seppelt R (2011) Exploring indicators for quantifying surface urban heat islands of European cities with MODIS land surface temperatures. Remote Sens Environ 115: 3175-3186. doi:10.1016/j.rse.2011.07.003 
Schwarz N, Schlink U, Franck U, Grossmann K (2012) Relationship of land surface and air temperature and its implications for quantifying urban heat island indicators - an application for the city of Leipzig (Germany). Ecol Indic 18:693-704. doi:10.1016/j.ecolind.2012.01. 001

Sobrino JA, Raissouni N (2000) Toward remote sensing methods for land cover dynamic monitoring: application to Morocco. Int J Remote Sens 21:353-366. doi:10.1080/014311600210876

Soper D. S. (2015) A-priori sample size calculator for multiple regression [software]. Available from http://www.danielsoper.com/statcalc. Accessed 15 October 2015

Steeneveld GJ, Koopmans S, Heusinkveld BG, van Hove LWA, Holtslag AAM (2011) Quantifying urban heat island effects and human comfort or cities of variable size and urban morphology in the Netherlands. J Geophys Res 116:D20129. doi:10.1029/ 2011JD015988

Stewart ID (2011) A systematic review and scientific critique of methodology in modern urban heat island literature. Int J Climatol 31:200 217. doi:10.1002/joc. 2141

Stopa-Boryczka M., Kopacz-Lembowicz M., Wawer J. (2001), Klimat Warszawy w pracach Zakładu Klimatologii Uniwersytetu Warszawskiego. The climate of Warsaw in the work of the Department of Climatology, University of Warsaw. In: Badania środowiska fizycznogeograficznego aglomeracji warszawskiej. Environmental Studies of Warsaw agglomeration, Prace Geograficzne 180, 57-69

Sun YJ, Wang JF, Zhang RH, Gillies RR, Xue Y, Bo YC (2005) Air temperature retrieval from remote sensing data based on thermodynamics. Theor Appl Climatol 80:37-48

Szymanowski M. (2004), Miejska wyspa ciepła we Wrocławiu. Urban heat island in Wrocław, Acta Univesitatis Wratislaviensis 2690, Studia Geograficzne, 77, Wyd. Uniwersytetu Wrocławskiego, Wrocław

Szymanowski M, Kryza M (2009) GIS-based techniques for urban heat island spatialization. Climate Res 38:171-187. doi:10.3354/cr00780
Tereshchenko IE, Filonov AE (2001) Air temperature fluctuations in Guadalajara, Mexico, from 1926 to 1994 in relation to urban growth. Int J Climatol 21:483-494. doi:10.1002/joc.602

Utsunomiya Y. (1992) Construction of a global environment database from satellite remote sensing data - estimation of air temperature on Kyushu Island, Southern Japan, from Landsat 5 TM data and ground station meteorological data. ISPRS Archives, Vol. XXIX Part B, 406-411

van Hove LWA, Jacobs CMJ, Heusinkveld BG, Elbers JA, van Driel BL, Holtslag AAM (2015) Temporal and spatial variability of urban heat island and thermal comfort within the Rotterdam agglomeration. Build Environ 83:91-103. doi:10.1016/j. buildenv.2014.08.029

Voogt J. A. (2004) Urban heat islands: hotter cities. American Institute of Biological Sciences. http://www.actionbioscience.org/environment/ voogt.html. Accessed 19 August 2013

Voogt JA, Oke TR (2003) Thermal remote sensing of urban climates. Remote Sens Environ 86:370-384. doi:10.1016/S0034-4257(03) 00079-8

Walawender J (2009) Wykorzystanie danych satelitarnych Landsat i technik GIS w badaniach warunków termicznych miasta (na przykładzie aglomeracji krakowskiej) (Application of LANDSAT satellite data and GIS techniques for estimation of thermal conditions in urban area (using an example of Kraków agglomeration)). Prace Geograficzne 122:81-98

Wloczyk C, Borg E, Richter R, Miegel K (2011) Estimation of instantaneous air temperature above vegetation and soil surfaces from Landsat 7 ETM+ data in northern Germany. Int J Remote Sens 32(24):9119-9136. doi:10.1080/01431161.2010.550332

Woś A (2010) Klimat Polski w drugiej połowie XX wieku (Polish climate in the second half of the twentieth century). Wyd. Naukowe UAM, Poznań

Zhang F, Cai X, Thornes JE (2014) Birmingham's air and surface urban heat islands associated with Lamb weather types and cloudless anticyclonic conditions. Prog Phys Geogr 38:431-447. doi:10.1177/ 0309133314538725 